\title{
Moringa oleifera Teabags Increase Hemoglobin in Adolescent Females
}

Gusti Ayu Tirtawati*, Kusmiyati Kusmiyati, Atik Purwandari, Amelia Donsu, Martha Korompis, Wahyuni Wahyuni, Fonnie Kuhu, Femmy Keintjem, Sjenny Tuju, Robin Rompas, Agnes Montolalu

Department of Midwifery, Poltekkes Kemenkes Manado, Manado, North Sulawesi, Indonesia

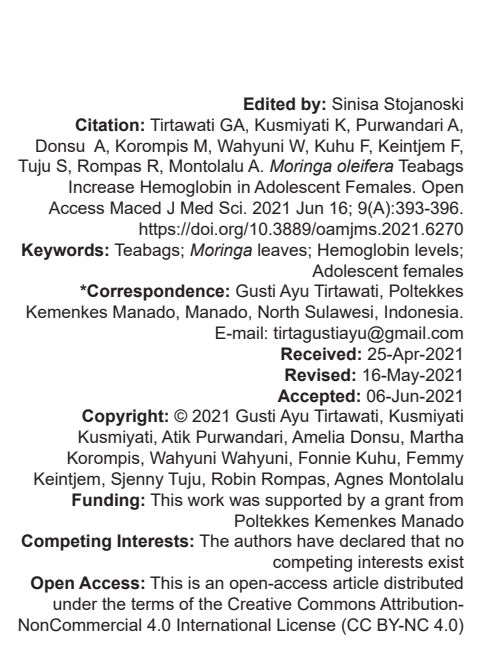

\section{Abstract}

AIM: The study aims to determine the effect of Moringa oleifera teabags on increased Hemoglobin $(\mathrm{Hb})$ in adolescent girls.

METHODS: The research method used in this research was a pre-post-test one group design, a research design to determine the cause and effect or effect of an intervention. The treatment was carried out by giving $M$. oleifera teabags 2 times. Specifically, one sachet $(3 \mathrm{~g})$ in the morning and one sachet $(3 \mathrm{~g})$ in the afternoon, dipped in $250 \mathrm{~m}$ hot water, and added two teaspoons granulated sugar. The treatment was given for 30 days.

RESULTS: An increase in the average of $\mathrm{Hb}$ (mean) before the intervention was $10.71 \mathrm{~g} / \mathrm{dl}$. After 15 days of the intervention, it was $11.03 \mathrm{~g} / \mathrm{dl}$. Subsequently, after 30 days of intervention, the average $\mathrm{Hb}$ value (mean) was $11.63 \mathrm{~g} / \mathrm{dl}$, then the $\mathrm{p}$-value $\leq \alpha$, which was $0.000(\mathrm{p}<0.05)$, and these results indicated a significant difference between $\mathrm{Hb}$ before and after the intervention.

CONCLUSION: There was a significant difference between $\mathrm{Hb}$ before and after the intervention, meaning that there was an effect of Moringa leaf teabags on the increase in $\mathrm{Hb}$ in adolescent females.

\section{Introduction}

Adolescents are undergoing various transitional period changes, both from a biological, psychosocial, intellectual, and economic perspective [1]. This change makes adolescents vulnerable to nutritional problems because they are experiencing rapid growth [2]. Their activities are increasing so that they require more energy and nutrients. Therefore, it deserves special attention because it affects the growth and development of the body and adulthood's current and future health.

A nutritional problem that is often experienced by adolescents is anemia. Anemia can reduce the body's resistance so that it is susceptible to disease; reduce activity and fitness, thereby hindering youth achievement and productivity [3]. Anemia often affects young women than men [4]. It is due to stress, menstruation, or eating late [5].

One of the efforts to overcome anemia in adolescent girls is to increase the intake of nutrients from local foods to meet their nutritional needs, such as Moringa oleifera leaves [6]. M. oleifera leaves are known to have various kinds of nutritional content, that is, iron, protein, Vitamin A, Vitamin C, potassium, calcium, and antioxidants [7]. Moringa leaves contain higher iron than other vegetables, about $26 \mathrm{mg} / 100 \mathrm{~g}$ [8].

Several other studies have also shown that giving Moringa leaves in tea to anemic adolescents is considered high effectiveness [9], [10]. Therefore, this study aims to determine the effect of $M$. oleifera teabags on increased hemoglobin $(\mathrm{Hb})$ in adolescent girls.

\section{Methods}

The research method used in this research was a pre-post-test one group design, a research design to determine the cause and effect or effect of an intervention/treatment. The pre- and post-test was conducted in one group, involving about 100 female adolescents. The treatment was carried out by giving $M$. oleifera teabags 2 times. Specifically, one sachet (3 g) in the morning and one sachet $(3 \mathrm{~g})$ in the afternoon, dipped in $250 \mathrm{ml}$ hot water, and added two teaspoons granulated sugar. The treatment was given for 30 days. 
Data analysis was Paired t-test with a significant level of $p<0.05$ and used SPSS. The protocol of this study had been approved by the Ethical Committee of Manado Health Polytechnic Ministry of Health (No. KEPK.01/04/025/2020).

\section{Results}

\section{Univariate analysis}

Table 1 shows that adolescent women involved in this study were mostly 15 years old (42.5\%), and the rests were 14 years old $(39.0 \%)$ and 13 years old $(19.0 \%)$.

Based on $\mathrm{Hb}$, Table 1 also shows that 25 respondents $(25.0 \%)$ before the intervention were in anemia, and $75(75.0 \%)$ were not in anemia. It changed after the 15 days intervention, about 12 respondents $(12.0 \%)$ were anemic, and about 88 respondents $(88.0 \%)$ did not experience anemia. Interventions continued for 30 days and showed a significant change. It appeared that there was no anemia in adolescent girls (100\%) after 30 days of intervention.

Table 1: Respondent Characteristics $(n=100)$

\begin{tabular}{lll}
\hline Characteristics & $\mathrm{n}$ & $\%$ \\
\hline Ages & 19 & \\
13 years & 39 & 19.0 \\
14 years & 42 & 39.0 \\
15 years & & \\
Hb & & \\
Before intervention & 25 & 25.0 \\
$\quad$ Anemia & 75 & 75.0 \\
$\quad$ Non-anemia & 12 & 12.0 \\
After intervention (15 days) & 88 & 88.0 \\
$\quad$ Anemia & & 100.0 \\
$\quad$ Non-Anemia & 0 & 100.0 \\
After intervention (30 days) & 100 & \\
$\quad$ Anemia & & \\
$\quad$ Non-anemia & & \\
Hb: Hemoglobin. & &
\end{tabular}

\section{Bivariate analysis}

Table 2 shows an increase in the average of $\mathrm{Hb}$ (mean) before the intervention was $10.71 \mathrm{~g} / \mathrm{dl}$. After 15 days of the intervention, it was $11.03 \mathrm{~g} / \mathrm{dl}$. Subsequently, after 30 days of intervention, the average $\mathrm{Hb}$ value (mean) was $11.63 \mathrm{~g} / \mathrm{dl}$, then the $\mathrm{p}$-value $\leq \alpha$, which was $0.000(p<0.05)$, and these results indicated a significant difference between $\mathrm{Hb}$ before and after the intervention.

Table 2: Differences in $\mathrm{Hb}$ before and after the intervention

\begin{tabular}{llllll}
\hline $\mathrm{Hb}$ & Mean & $\mathrm{SD}$ & \multicolumn{2}{l}{$\begin{array}{l}\text { 95\% confidence interval of } \\
\text { the difference }\end{array}$} & p-value \\
\cline { 4 - 5 } & & & Lower & Upper & \\
\hline Before intervention & 10.71 & 1.04469 & 8.40 & 12.60 & $0.000^{*}$ \\
After 15 days intervention & 11.03 & 1.05282 & 9.30 & 12.80 & \\
After 30 days intervention & 11.63 & 0.89498 & 9.80 & 13.00 & \\
\hline
\end{tabular}

Hb: Hemoglobin.

\section{Discussion}

One of the preventions of anemia in young women is to utilize local plants in the community, such as M. oleifera leaves. Moringa leaves contain high enough iron and vitamins suitable for improving $\mathrm{Hb}$ function [11]. $\mathrm{Hb}$ in blood cells functions to bind oxygen, oxygen bound, and carried by $\mathrm{Hb}$ in red blood cells. Oxygen supply to various places throughout the body will also be achieved, reducing the risk of ischemia, leading to dysmenorrhea in anemic adolescent [12], [13].

This study uses Moringa leaves packaged in tea bags, making it easy to consume, more safety, and increase shelf life. The results showed that according to $\mathrm{Hb}$, about 88 (88\%) female adolescents after 15 days of intervention were not anemic while those experiencing anemia had decreased, were 12 respondents (12\%). Even after 30 days of intervention, there was a significant increase; about 100 respondents (100\%) were not anemic. Before the increase in $\mathrm{Hb}$ mean before the intervention was $10.71 \mathrm{~g} / \mathrm{dl}$. After 15 days of intervention, the average $\mathrm{Hb}$ was $11.03 \mathrm{~g} / \mathrm{dl}$. After 30 days of intervention, the average was $11.63 \mathrm{~g} / \mathrm{dl}$ with $p$-value $<\alpha$, which was $0.000(p<0.05)$. These results indicated there was a significant difference between $\mathrm{Hb}$ before and after the intervention.

Consuming Moringa leaf extract can increase $\mathrm{Hb}$ levels in the blood [14]. Moringa leaf extract is suitable for adolescent girls, especially those with anemia [15]. When anemia occurs, there is an increase in iron absorption due to high demand. There is an increase after intervention in giving Moringa leaf extract contains iron and Vitamin $\mathrm{C}$, which can help iron absorption. Based on laboratory analysis results, the nutritional composition of Moringa leaf extract (Sulawesi varieties) includes $25.25 \%$ protein, $91.72 \mathrm{mg}$ iron, $33.991 .51 \mathrm{ug}$ Vitamin A, $1125.71 \mathrm{mg}$ Vitamin C, and 3.34\% Vitamin E in every $100 \mathrm{~g}$ of material. Moringa leaves contain $773 \mathrm{mg}$ of Vitamin C for every $100 \mathrm{~g}$ of dry matter.

Various studies have also stated that $M$. oleifera leaves have various kinds of nutritional content easily digested by the human body. Some of them are iron, protein, Vitamin A, Vitamin C, potassium, calcium, and antioxidants. Moringa leaves contain higher iron than other vegetables, which is $26 \mathrm{mg} / 100 \mathrm{~g}$. The iron (Fe) content in dried Moringa leaves or Moringa leaf flour is equivalent to 25 times higher than spinach [7], [16].

Moringa leaves have considerable potential for nutrients, various macro and micronutrients, and active ingredients act as antioxidants. Furthermore, it contains essential nutrients such as $28.2 \mathrm{mg} \mathrm{Fe}, 2003.0 \mathrm{mg}$ calcium, and $16.3 \mathrm{mg}$ Vitamin A. Other nutrients include protein, C, Vitamin D, Vitamin E, Vitamin K, and Vitamin B (thiamine, riboflavin, niacin, pantothenic acid, biotin, Vitamin B6, Vitamin B12, and folate). The Vitamin C content in Moringa leaf extract also facilitates 
iron absorption [14]. Moringa is also used as the main ingredient in hundreds of medicines, both for prevention and treatment [17].

Based on various studies, tea in Moringa leaves is very nutritious, and nutritionists and dietitians have recognized its benefits. Moringa leaf tea's recommended dose is $5 \mathrm{~g} /$ day, about one tea bag $(2.5 \mathrm{~g})$ in the morning, and one tea bag in the evening. The use of Moringa leaf dosages is adjusted to research considerations safe for consumption by young women. However, this Moringa leaf tea can be a source of oxidants, anti-inflammatory, and high nutrients [18].

Hundred grams of Moringa powder contain many amino acids that can help prevent the polymerization process and iron precipitation. Furthermore, Moringa contains ascorbic acid, a potent iron absorption stimulant. It functions as a reducing agent, converts ferries into ferrous oxide, maintains intestinal $\mathrm{pH}$, and preventing iron precipitation. Besides, it may act as a chelator to forms iron-ascorbate; make it more easily absorbed by the body.

Moringa leaves are useful for anemic patients in low and relatively high doses. The significant increase in the number of red blood cells (erythrocytes) and white blood cells (leukocytes) with Moringa leaves' treatment shows that it is suitable as a dietary supplement and a drug for anemia patients [19].

\section{Conclusion}

$\mathrm{Hb}$ before the intervention was $10.71 \mathrm{~g} / \mathrm{dl}$ on average. Hb levels after 15 days of the intervention were $11.03 \mathrm{~g} / \mathrm{dl}$ on average, with an increase of $0.32 \mathrm{~g} / \mathrm{dl}$. After 30 days of intervention, the average $\mathrm{Hb}$ average was $11.63 \mathrm{~g} / \mathrm{dl}$, with an increase of $0.6 \mathrm{~g} / \mathrm{dl}$ from the first intervention (15 days intervention) and an increase of $0.92 \mathrm{~g} / \mathrm{dl}$ from before the intervention (0 days). There was a significant difference between $\mathrm{Hb}$ before and after the intervention, meaning that there was an effect of Moringa leaf teabags on the increase in $\mathrm{Hb}$ in adolescent girls. It is expected that young female is drinking Moringa leaf teabags diligently to prevent anemia.

\section{References}

1. National Academies of Sciences, Engineering, and Medicine, Health and Medicine Division, Division of Behavioral and Social Sciences and Education, Board on Children, Youth, and Families,
Committee on the Neurobiological and Socio-behavioral Science of Adolescent Development and Its Applications, Backes EP, et al., editors. The Promise of Adolescence: Realizing Opportunity for all Youth. Washington, DC: National Academies Press (US); 2019. https://doi.org/10.17226/25388

2. Christian P, Smith ER. Adolescent undernutrition: Global burden, physiology, and nutritional risks. Ann Nutr Metab. 2018;72(4):316-28. https://doi.org/10.1159/000488865 PMid:29730657

3. Abbaspour N, Hurrell R, Kelishadi R. Review on iron and its importance for human health. J Res Med Sci. 2014;19(2):164-74. PMid:24778671

4. Alvarez-Uria G, Naik PK, Midde M, Yalla PS, Pakam R. Prevalence and severity of anaemia stratified by age and gender in rural India. Anemia. 2014;2014:176182. https://doi. org/10.1155/2014/176182

PMid:25614831

5. Chaparro CM, Suchdev PS. Anemia epidemiology, pathophysiology, and etiology in low-and middle-income countries. Ann N Y Acad Sci. 2019;1450(1):15-31. https://doi. org/10.1111/nyas. 14092

PMid:31008520

6. Nadimin, Hadju V, As S, Buchari A. The extract of moringa leaf has an equivalent effect to iron folic acid in increasing hemoglobin levels of pregnant women: A randomized control study in the coastalarea ofmakassar. Int JSciBasicAppIRes. 2015;22(1):28794. https://doi.org/10.5958/0976-5506.2019.00102.5

7. Gopalakrishnan L, Doriya K, Kumar DS. Moringa oleifera: A review on nutritive importance and its medicinal application. Food Sci Human Wellness. 2016;5(2):49-56. https://doi. org/10.1016/j.fshw.2016.04.001

8. Aminah S, Ramdhan T, Yanis M. The nutritional content and functional properties of the Moringa (Moringa oleifera). Bul Pertanian Perkotaan. 2015;5(2):35-44.

9. Suzana D, Suyatna FD, Azizahwati A, Andrajati R, Sari SP Mun'im A. Effect of Moringa oleifera leaves extract against hematology and blood biochemical value of patients with iron deficiency anemia. J Young Pharm. 2017;9(1):S79-84. https:// doi.org/10.5530/jyp.2017.1s.20

10. Shija AE, Rumisha SF, Oriyo NM, Kilima SP, Massaga JJ. Effect of Moringa oleifera leaf powder supplementation on reducing anemia in children below two years in Kisarawe District, Tanzania. Food Sci Nutr. 2019;7(8):2584-94. https://doi. org/10.1002/fsn3.1110

PMid:31428346

11. Mustapa $Y$, Hadju V, Indriasari R, Hidayanti $H$, Sirajuddin $S$, Russeng SS. The effect of Moringa oleifera to hemoglobin levels of preconception women in the health center Tibawa district Tibawa, Gorontalo. Open Access Maced J Med Sci. 2020;8(T2):104-8. https://doi.org/10.3889/oamjms.2020.5201

12. Bobak. Buku Ajar Keperawatan Maternitas. Jakarta: EGC; 2004.

13. Kusumawardan PA, Cholifah $\mathrm{S}$. The relations between anemia and female adolescent's dysmenorrhea. In: Universitas Ahmad Dahlan International Conference on Public Health. Yogyakarta: Universitas Ahmad Dahlan; 2018. p. 190-5. https://doi. org/10.29333/iji.2019.12139a

14. Anisa N, Wahyuni S, Rahayu S, Choirunnisa A, Eko Martanti L. Effect of moringa leaves and Vitamin $C$ capsule combinations in increaseing hemoglobin levels of young women with anemia. In: Proceedings of International Conference on Applied Science and Health. Thailand: Mahidol University; 2019. p. 565-70.

15. Sartika W, Suryarinilsih $Y$, Herwati. The effect of moringa leaf capsule on the hemoglobin levels in young women at SMP 
Sabbihisma Padang. KnE Life Sci. 2019;2019:158-64. https:// doi.org/10.18502/kls.v4i15.5753

16. Rockwood JL, Anderson BG, Casamatta D. Potential uses of Moringa oleifera and an examination of antibiotic efficacy conferred by $M$. oleifera seed and leaf extracts using crude extraction techniques available to underserved indigenous populations. Int J Photother Res. 2013;3:61-71.

17. Matic I, Guidi A, Kenzo M, Mattei M, Galgani A. Investigation of medicinal plants traditionally used as dietary supplements: A review on Moringa oleifera. J Public Health Afr. 2018;9(3):841. https://doi.org/10.4081/jphia.2018.841

PMid:30854178

18. Vergara-Jimenez M, Almatrafi MM, Fernandez ML. Bioactive components in Moringa oleifera leaves protect against chronic disease. Antioxidants (Basel). 2017;6(4):91. https://doi. org/10.3390/antiox6040091

PMid:29144438

19. Samuel SA, Francis AO, Onyinyechi U, Ayomide O. Effects of Moringa oleifera leaf extract on red and white blood cells counts. Int J Curr Med Pharm Res. 2015;1(9):150-61. 